\title{
Assessment of the Ecotoxicity of Pollution by Potentially Toxic Elements by Biological Indicators of Haplic Chernozem of Southern Russia (Rostov region)
}

\author{
Sergey Kolesnikov • Tatiana Minnikova • Kamil Kazeev • Yulia Akimenko • \\ Natalia Evstegneeva
}

Received: 6 August 2021 / Accepted: 29 December 2021 / Published online: 5 January 2022

(C) The Author(s), under exclusive licence to Springer Nature Switzerland AG 2022

\begin{abstract}
The content of various chemical elements such as metals, metalloids, and nonmetals in the environment is associated with natural and anthropogenic sources. It is necessary to normalize the content of metals, metalloids, and nonmetals as potentially toxic elements (PTE) in the Haplic Chernozem. The soils of the Southern Russia are of high quality and fertility. However, this type of soil, like Haplic Chernozem, is subject to contamination with a wide range of PTE. The aim of the work was to rank metals, metalloids, and nonmetals by ecotoxicity in Haplic Chernozem. To assess the ecotoxicity of chernozem, data for 15 years (2005-2020) were used. Biological indicators used to assess the ecotoxicity of Haplic Chernozem: catalase activity, cellulolytic activity, number of bacteria, Azotobacter spp. abundance, to change of length of radish's roots. Based on these biological
\end{abstract}

\footnotetext{
S. Kolesnikov · T. Minnikova $(\bowtie) \cdot$ K. Kazeev

Y. Akimenko $\cdot$ N. Evstegneeva

Academy of Biology and Biotechnology Named

D.I. Ivanovsky, Southern Federal University,

344090 Rostov-on-Don, Russia

e-mail: loko261008@yandex.ru

S. Kolesnikov

e-mail: kolesnikov1970@list.ru

K. Kazeev

e-mail: kamil_kazeev@mail.ru

Y. Akimenko

e-mail: akimenkojuliya@mail.ru

N. Evstegneeva

e-mail: natalja.evstegneewa@yandex.ru
}

indicators, an integral indicator of the state of Haplic Chernozem was calculated. The ecotoxicity of 23 metals $(\mathrm{Cd}, \mathrm{Hg}, \mathrm{Pb}, \mathrm{Cr}, \mathrm{Cu}, \mathrm{Zn}, \mathrm{Ni}, \mathrm{Co}, \mathrm{Mo}, \mathrm{Mn}, \mathrm{Ba}$, $\mathrm{Sr}, \mathrm{Sn}, \mathrm{V}, \mathrm{W}, \mathrm{Ag}, \mathrm{Bi}, \mathrm{Ga}, \mathrm{Nb}, \mathrm{Sc}, \mathrm{Tl}, \mathrm{Y}, \mathrm{Yb}), 5$ metalloids (B, As, Ge, Sb, Te) and 2 nonmetals (F, Se) as priority pollutants. It is proposed to distinguish three hazard classes of metals, metalloids, and nonmetals to Haplic Chernozem: I class - Te, Ag, $\mathrm{Se}, \mathrm{Cr}, \mathrm{Bi}$, $\mathrm{Ge}, \mathrm{Sn}, \mathrm{Tl}, \mathrm{Hg}, \mathrm{Yb}, \mathrm{W}, \mathrm{Cd}$; II class - As, Co, Sc, $\mathrm{Sb}, \mathrm{Cu}, \mathrm{Ni}, \mathrm{B}, \mathrm{Nb}, \mathrm{Pb}, \mathrm{Ga}$; III class - Sr, Y, Mo, Zn, $\mathrm{V}, \mathrm{Ba}, \mathrm{Mn}, \mathrm{F}$. It is advisable to use the results of the study for predictive assessment of the impact of metals, metalloids, and nonmetals on the ecological state of the soil during pollution.

Keywords Pollutants $\cdot$ Metals $\cdot$ Metalloids · Nonmetals $\cdot$ Ecotoxicity $\cdot$ Biotesting $\cdot$ Haplic Chernozem $\cdot$ Ranking $\cdot$ Hazard classes

\section{Introduction}

All chemical elements of planet Earth are divided into 3 groups: metals, nonmetals, and metalloids (with the properties of both metals and non-metals). Among all the chemical elements, there are essential elements for life (essential elements), and some metals, metalloids or nonmetals that are very toxic and dangerous like arsenic, mercury, lead. According to the World Health Organization, only 11 metals are considered potentially toxic elements (PTE): arsenic, 
cadmium, cobalt, chromium, copper, mercury, manganese, nickel, lead, tin, and titanium (Index, 2018). The contamination chain of PTE or heavy metalls almost usually follows from industry to the atmosphere, soil, water, and foods then human (Pourret et al., 2021; Krishna \& Mohan 2016). In most ores, heavy metals such as $\mathrm{As}, \mathrm{Fe}, \mathrm{Pb}, \mathrm{Zn}, \mathrm{Au}, \mathrm{Ni}, \mathrm{Ag}$, and $\mathrm{Co}$ exist as sulfides while others such as $\mathrm{Mg}, \mathrm{Al}$, $\mathrm{Se}, \mathrm{Au}$, and $\mathrm{Sb}$ exist as oxides. Certain heavy metals such as $\mathrm{Cu}, \mathrm{Fe}$, and Co can exist both as sulfide and oxide ores (Engwa et al., 2019; Sani \& Amanabo, 2021; Rudakiya \& Patel, 2021). More so, the industrial products such as paints, cosmetics, pesticides, and herbicides also serve as sources of heavy metals.

The health of a modern person during the period of illness is directly related to the incoming PTEs (Esplugas et al., 2019; Cannas et al., 2020; Fedele et al., 2021). Essential micro- and macroelements include heavy metals. With a lack of some trace elements, human immunity decreases, in the case of compensation with heavy metals, a negative effect on the body is also observed. The current SARS-CoV-2/ COVID-19 epidemic has had a significant impact on the health of citizens (Domingo \& Marquès, 2021). Consideration should be given to the role of metals and metalloids in the treatment of this disease. Metals and metalloids such as arsenic, cadmium, lead, mercury or vanadium are elements that have toxic effects on living organisms, while essential trace elements such as cobalt, copper, iron, manganese, selenium, and zinc are considered essential (Nadal et al., 2011; Domingo et al., 2017; Hoang \& Han, 2020). According to (GOST 1983; Quing, 2015), chemical elements (metals, metalloids, and nonmetals) are ranged into hazard classes with respect to human health. However, results of previous studies (Crommentuijn et al., 1997; Kolesnikov et al., 2010, Vodyanitskii, 2012; Xiong et al., 2015) have shown that many elements do not correspond to the specified hazard classes (degrees) in terms of the effects on soil state and it is advisable to develop their own hazard classes for soil ecosystems. In recent years, the problem of assessing PTE (metals, non-metals, and metalloids) by hazard classes has undergone some changes. The toxicity of many metals and metalloids has been revised; in this regard, it becomes necessary to update the hazard classes of chemical elements in connection with the latest trends.
The ecotoxicity of such elements as $\mathrm{Te}, \mathrm{Se}, \mathrm{Ag}, \mathrm{Bi}$, $\mathrm{Ge}$, and $\mathrm{Tl}$ is currently underestimated (Vodyanickii, 2012; Kolesnikov et al., 2020, 2021). This is since their pollution is much less common than, for example, $\mathrm{Hg}, \mathrm{Cd}, \mathrm{Pb}, \mathrm{Cu}, \mathrm{Zn}, \mathrm{Cr}$, and $\mathrm{Ni}$ (Kabata-Pendias 2010). In case of contamination of soil with Te, Se, $\mathrm{Ag}, \mathrm{Bi}, \mathrm{Ge}$, and $\mathrm{Tl}$, no statistically significant effect of "hormesis" was observed at any single dose or biological indicator, unlike most metals and metalloids that are considered very dangerous, such as $\mathrm{Hg}, \mathrm{Cd}$, $\mathrm{Pb}, \mathrm{Cr}, \mathrm{Ni}, \mathrm{Cu}, \mathrm{Zn}$, etc. (Val'kov et al., 1999; Kolesnikov et al., 2000, 2019; Plyatsuk et al., 2019). It is also important to note that the two most ecotoxical elements, Te and Se, are chemical analogs. According to the influence on the soil condition, the studied elements are not classified according to the hazard classes developed in relation to human health and differ from them very significantly (GOST, 1983) or not so significantly (Qing et al., 2015).

Soil pollution with bismuth affects the state of ecosystems and human health (Wei et al., 2011; Yang and Sun, 2011; Unai Cortada et al. 2018; Li et al., 2014; Xiong et al., 2015). Ore deposits containing Bi increase its background content in the soil cover up to 300 ppm (Yurgenson \& Gorban 2017). It is observed negative of $\mathrm{Bi}$ on soil enzymatic activity and soil bacteria, plants, earthworms, and humans (Murata, 2006; Liu et al., 2011; Ni et al., 2011; Omouri et al., 2018). Bismuth, like lead, enters the soil to form carbonates (Murata, 2010). In more acidic soils (Andosol) compared to alkaline soils (Cambisol, Regosol \& Fluvisol), bismuth is quite mobile and toxic to biota (Murata et al., 2018).

Thallium is one of the least studied chemical elements. Among anthropogenic sources, thallium enters the environment because of human mining activities, as well as the burning of coal (Viraraghavan and Srinivasan 2011). The background content of thallium in soils is from $0.3 \mathrm{mg} / \mathrm{kg}$ (soils in China and France) to $2.8 \mathrm{mg} / \mathrm{kg}$ (geochemical anomaly in the south of Western Siberia) (Il'in \& Konarbaeva, 2000; LaCoste et al. 1999; Huang et al., 2016). Thallium influences the indices of plant seed germination, chlorophyll content, and enzymatic activity of soils (Pavlickova et al. 2005, 2006; Ferronato et al. 2016; Guo et al. 2018; Kolesnikov et al., 2021; Luo et al. 2020). Thallium has a toxic effect on the soil and has a high accumulation rate in plants (Baceva et al., 2014; Sabermahani et al., 2016; Sizmur et al., 2016). 
Selenium concentration in soil varies within $0.01-2.0 \mathrm{mg} / \mathrm{kg}$, but maximum concentrations of $5 \mathrm{mg} / \mathrm{kg}$ were observed in Ireland, China, India, and the USA (Manojlović, 2003; Saha et al. 2017). Selenium belongs to essential trace elements, the presence of which and inclusion in the food chain is necessary at low concentrations. Depending on the concentration and reaction of the soil environment and the redox potential, the toxicity of selenium can vary (Chen et al. 2006, Mayland et al. 1989). As a result of industrial combustion of coal, much more selenium is released into the air than when burning petroleum hydrocarbons: coal contains more $\mathrm{Se}(3 \mathrm{mg} / \mathrm{kg})$ than oil (to 0.02 till $2 \mathrm{mg} / \mathrm{kg}$ ) (Lakin, 1973; Ellrich et al., 1985). Burning fossil fuels releases high concentrations of Se into the atmosphere, which is separated into submicron particles (Mayland et al., 1989). Selenium accumulates well in the root system and aboveground organs of plants, such as astragalus (Astragalus bisulcatus L.) and stenlea (Stanleya pinnata L.), contain from 1000 to $15,000 \mathrm{mg} / \mathrm{kg}$ Se (Quinn et al., 2010; Sura-de Jong et al., 2015).

It is known that when coal is burned, $50 \%$ of the total weight of the silver contained in it enters the atmosphere (Kizilshtein \& Levchenko 2003). Over half a century in China, about 3864 tons of silver got into the atmosphere by burning coal (Xing et al., 2004). The content of silver and its toxicity to the environment has been growing at an exponential rate over the past half century with increasing trends (Kasimov \& Vlasov 2012; Aueviriyavit et al., 2014; Benn et al., 2010). In contaminated soils, the silver content according to various sources ranges from 8 to $7000 \mathrm{mg} \mathrm{kg}^{-1}$ in soils of ore deposits (Jones et al., 1986; Druzhinin \& Karelina 2008; Kabata-Pendias, 2010; Puzanov et al., 2015; Yildirim \& Sasmaz 2017). Silver causes inhibition of enzyme activity and a decrease in the permeability of biological membranes, DNA damage, metabolic disturbances and causes cell death (Liu et al., 2011, 2018; Reidy et al. 2013; Sun et al., 2016; Gomathi et al., 2017; Sayeda \& Solimanb Hamdy 2017; Sharma et al., 2014). Such regulation mechanisms are associated with the structure of the soil and the reaction of the soil environment (Benini et al., 2014; Kaya et al., 2015).

Germanium is widespread in the earth's crust. It is called a pseudo isotope of silicon ( $\mathrm{Si}$ ). Like silicon, Ge shows very similar chemical characteristics, but the mechanisms of influence of soil organic matter on the mobility and bioavailability of Ge in the soil-plant system remain unclear (Wiche et al. 2018;. Yamaji \& Ma, 2009). Due to the high mobility of Si and $\mathrm{Ge}$ in the soil in various plant species, especially grasses, Ge and $\mathrm{Si}$ are absorbed and transported from the soil throughout all plant organs (Ma et al. 2003; Ma et al. 2003; Ma et al. 2007, 2011; Mitani et al. 2009; Yamaji \& Ma 2009; Yamaji \& Sun 2011; Pontigo et al. 2015). Considering this mobility, a series of absorption of germanium by the organs of plants of maize (Zea mays L.), oats (Avena sativa L.) and canary grass (Phalaris arundinacea L.) was constructed: roots $<$ stems < leaves (Kaiser 2015). In plant roots, the content of elements varied: they were $0.53 \mathrm{mg} \mathrm{Ge}$ and $8.66 \mathrm{mg} \mathrm{Si}$ in Z. mays, $0.77 \mathrm{mg} \mathrm{Ge}$ and $17.77 \mathrm{mg} \mathrm{Si}$ in $P$. arundinacea and $0.07 \mathrm{mg} \mathrm{Ge}$ and $2.64 \mathrm{mg} \mathrm{Si}$ in A. sativa, respectively. The content of organic matter in the soil affects the mobility of Ge and its biological properties in the soil (Moschner et al., 2020; Fan et al. 2021a, 2021b; Kaiser et al. 2020). High levels of Ge atoms show low toxicity in the environment, and $\mathrm{Ge}$ oxides, like $\mathrm{GeO}_{2}$, are highly toxic (Rosenberg, 2009; Chen and Lin 2011). Germanium is contained in the soil in labile pools, which has a direct toxic effect on plants.

Southern of the European part of Russia include unique and fertile soils. The greatest agricultural potential of soils in the Southern of the European part of Russia is in the Rostov Region and Krasnodar Territory. The most fertile soils of this region are chernozems (Val'kov et al., 2008) It is on the territory of the Rostov region that soils are subject to the greatest anthropogenic load due to heavy traffic and many mining and processing enterprises, which affects its health and functions (Gorbov et al., 2015). The soils of the South of the European part of Russia (Rostov region) are subject to high pollution with potentially toxic elements (https://www.donnews.ru/). In the Rostov region, the zone of chronic pollution of the territory (2 times higher than the background values) occupies almost $26,000 \mathrm{~km}^{2}$, more than $25 \%$ of the region's territory (Cheshev, 2015). Such areas of the Rostov region include agricultural land areas located near large industrial centers. For example, in the area of the city Millerovo, the lead content is 1.5 times, and the zinc content is 1.3 times higher than the natural geochemical background (Aristarkhov et al., 2016; Cheshev, 2015). In the area of the city of Kamensk-Shakhtinsk, the soils have an increased 
content of lead, copper, molybdenum, barium, manganese, cobalt, nickel, and zinc.

In the all-Russian rating of Russian cities with the highest level of air pollution, there are also two Rostov cities - Novocherkassk and Rostov-onDon (donnews, 2020; Klimov, 2018). If in the city of Novocherkassk, a large coal-fired power plant Novocherkask PSE has a large impact, then in Rostov-on-Don, emissions from vehicles prevail (Abramenko et al., 2019). According to the State Program of the Government of the Rostov Region of 15.10.2018 No. 638 "Environmental protection and rational use of natural resources" 2019-2030, it is necessary to carry out regional state environmental supervision measures to control the condition of facilities (natural water, wastewater, industrial emissions, and atmospheric air, soil, waste, bottom sediments); mine surveying at objects of supervision (control) by specialized organizations (Environmental protection... 2018).

The purpose of the work is to carry out a comparative assessment of ecotoxicity and ranking of 30 PTEs by the degree of ecotoxicity of Haplic Chernozem.

\section{Material and Methods}

\subsection{Soil Site}

The research object is Haplic Chernozem Calcic according to IUSS Working Group (WRB, 2015). The soil was sampled in the upper layer (top layer of soil: $0-10 \mathrm{~cm}$ ) of arable land in the territory of the Persianovskaya Steppe Nature Reserve (Rostov region, Russia). This soil type was characterized as a heavy loam soil texture, $\mathrm{TOC}=8 \%$ and $\mathrm{pH}_{\mathrm{H} 2 \mathrm{O}}=7.8$ (nearly neutral).

For the experiment, Haplic Chernozem was taken from the virgin land plot of the Persianovskaya steppe (Fig. 1). Persianovskaya Steppe is a unique nature reserve in the Southern Russia with an area of 70 ha. It is a test site of the Don State Agrarian University. The plot is surrounded by forest strips on all sides. In the southeast, it is adjoined by the reserve "Dubrava named by V. V. Dokuchaev". Most of the reserve is virgin lands, only a small area along the eastern border is fallow. This reserve contains areas of virgin steppe and populations of endemic plants (Kazadeev et al., 2004; Val'kov et al., 2008).
Comparing the chernozems of the Persianovskaya Steppe Nature Reserve with arable chernozems and fallow soils, its unique properties and value have been proven (Azarenko 2014, Azarenko et al. 2020). The rich flora and fauna with an abundance of microorganisms in the soil determines a high level of fertility of chernozems (Kazadeev et al., 2004).

Haplic Chernozem is considered the most fertile soils in Russia and the world. The high fertility of this type of soil is also associated with the state of aggregation, water-holding capacity, activity of soil biota, and high buffering capacity of the soil to withstand high concentrations of pollutants (Val'kov et al., 2008, 2012).

The high fertility of chernozems was created by an almost 10-thousand-year history of development associated with the existence and influence of steppe vegetation. Herbaceous biocenoses for $70-80 \%$ of their roots live underground in close unity and interaction with the soil mass, creating the richest and fertility Haplic Chernozem.

\subsection{Metals, Metalloids, Nonmetals}

The results of model experiments to investigate the effect of contamination of Haplic Chernozem from 15 years (2005-2020) with various chemical elements on the ecological condition of Haplic Chernozem have been summarized (Kolesnikov et al. 2008a, 2009, 2011, 2014, 2019a,b, 2020; Popovich \& Kolesnikov 2005). Soil contamination with 30 chemical elements which are priority pollutants as metals $(\mathrm{Cd}, \mathrm{Hg}, \mathrm{Pb}, \mathrm{Cr}, \mathrm{Cu}, \mathrm{Zn}, \mathrm{Ni}, \mathrm{Co}, \mathrm{Mo}, \mathrm{Mn}, \mathrm{Ba}$, Sr, Sn, V, W, Ag, Bi, Ga, Nb, Sc, Tl, Y, Yb), metalloids (B, As, Ge, Sb, Te), and non-metals (F, Se) has been studied. This is also explained by the fact that soil technogenic pollution is very often caused by elemental oxides (Kabata-Pendias, 2010). The content of chemical elements (metals, metalloids and non-metals) in Haplic Chernozem was defined by inductively coupled Plasma Mass Spectrometry ELAN-DRC-e instrument (Perkin Elmer) (Table 1). The measuring range of chemical elements (metals, metalloids, and non-metals) of the mass spectrometer is from $10^{-5}$ to $0.1 \%$ in a laboratory of A.P. Karpinsky Russian Geological Research Institute, St. Petersburg (VSEGEI/ CGMW). 
A
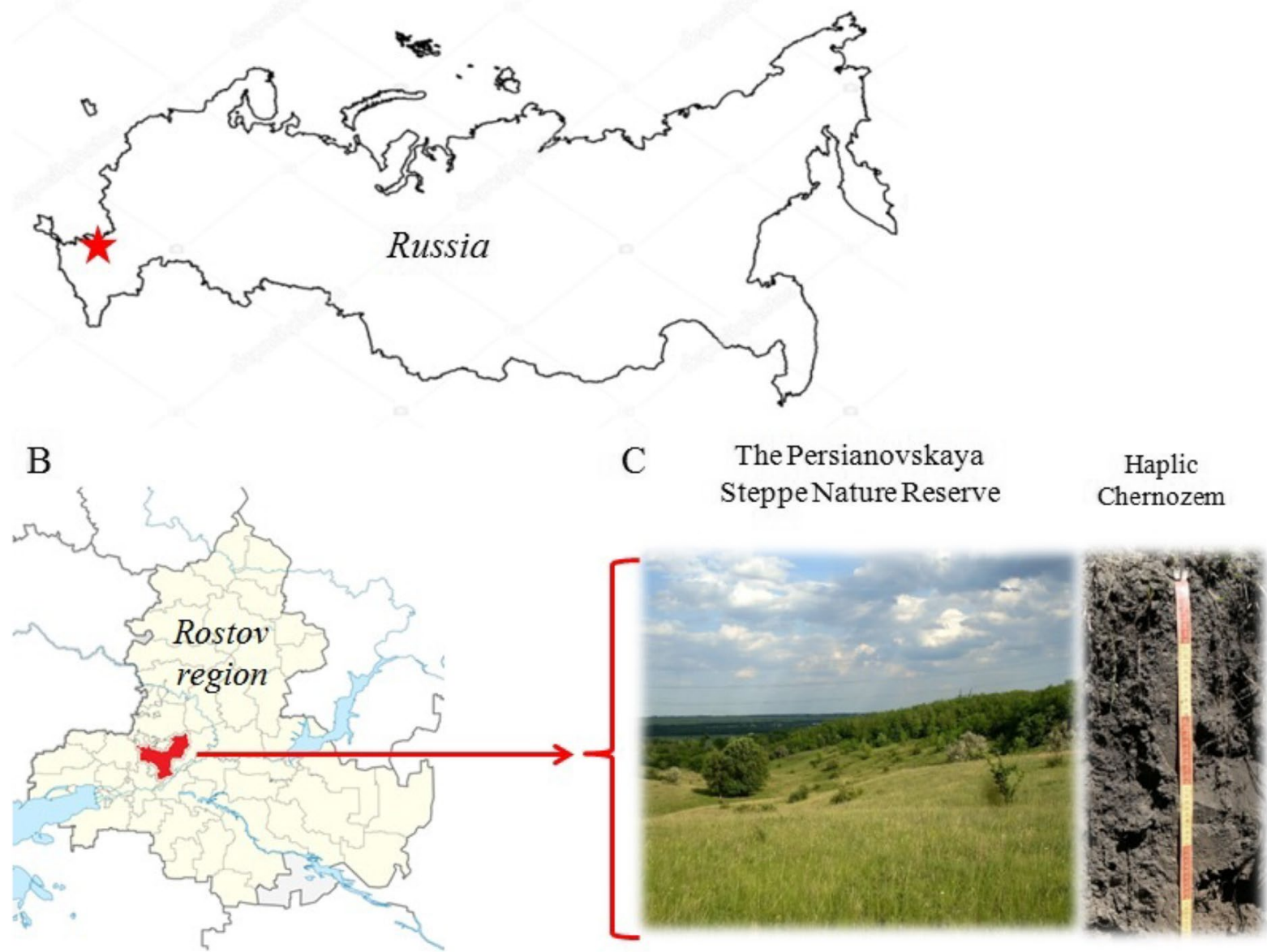

Fig. 1 Map of soil site. Note, (A) Map of Russia; (B) Rostov region; (C) the Persianovskaya Steppe Nature Reserve

\subsection{Experimental Details}

Often, toxicity of metals, metalloids, and non-metals are observed when their concentration in the soil reaches three to four background concentrations. This fact is confirmed by maximum permissible concentration (MPC) values of many heavy metals, which are often close to 3-4 background concentrations. Therefore, in our study, we used MPC concentration in $1 \mathrm{mg}$ of chemical elements of $1 \mathrm{~kg}$ of soil and mol of chemical elements of $1 \mathrm{~kg}$ of soil (Fig. 2).

MPC was assumed to be equal to three background concentrations of the element in the soil. The elements were introduced into the soil in an amount of 1 , 10 , and $100 \mathrm{MPC}$.
Samples of chernozem weighing $1 \mathrm{~kg}$ in 3 replicates were mixed with the required dose of metal oxide, metalloid and nonmetal. After that, the soil was thoroughly mixed with metal oxide and moistened. Soil samples were incubated in the vegetation vessels at a temperature of $20-22{ }^{\circ} \mathrm{C}$, soil moisture content of 55-60\%, and a soil density of $1.2 \mathrm{~g} / \mathrm{cm}^{3}$.

\subsection{Measurement Procedures}

Laboratory and analytical studies were carried out 30 days after contamination of Haplic Chernozem (Table 2).

The greatest negative effect of pollutant on the soil properties is revealed (Kolesnikov et al., 2014). Hazard degree of the element was estimated by the 
Table 1 Element content in soil in background concentration (BC) and maximum permissible concentrations (MPC) of Haplic Chernozem, mg/kg

\begin{tabular}{llllllll}
\hline No & Element & BC $^{*}$ & $1 \mathrm{MPC}$ & $\mathrm{No}$ & Element & BC $^{*}$ & $1 \mathrm{MPC}$ \\
\hline 1 & $\mathrm{Ag}$ & 1.04 & 3.12 & 16 & $\mathrm{Nb}$ & 16.2 & 48.6 \\
2 & $\mathrm{As}$ & 7.6 & 22.8 & 17 & $\mathrm{Ni}$ & 49 & 147 \\
3 & $\mathrm{~B}$ & 28.6 & 85.8 & 18 & $\mathrm{~Pb}$ & 27.9 & 83.7 \\
4 & $\mathrm{Ba}$ & 485 & 1455 & 19 & $\mathrm{Sb}$ & 1.08 & 3.24 \\
5 & $\mathrm{Bi}$ & 2.23 & 6.69 & 20 & $\mathrm{Sc}$ & 10.4 & 31.2 \\
6 & $\mathrm{Cd}$ & 0.23 & 0.69 & 21 & $\mathrm{Se}$ & 9.04 & 27.12 \\
7 & $\mathrm{Co}$ & 14.5 & 43.5 & 22 & $\mathrm{Sn}$ & 7.15 & 21.45 \\
8 & $\mathrm{Cr}$ & 107.9 & 323.7 & 23 & $\mathrm{Sr}$ & 233.3 & 699.9 \\
9 & $\mathrm{Cu}$ & 39.3 & 117.9 & 24 & $\mathrm{Te}$ & 0.063 & 0.189 \\
10 & $\mathrm{~F}$ & 193 & 579 & 25 & $\mathrm{Tl}$ & 1.23 & 3.69 \\
11 & $\mathrm{Ga}$ & 18.3 & 54.9 & 26 & $\mathrm{~V}$ & 98.7 & 296.1 \\
12 & $\mathrm{Ge}$ & 2.31 & 6.93 & 27 & $\mathrm{~W}$ & 1.62 & 4.86 \\
13 & $\mathrm{Hg}$ & 0.078 & 0.234 & 28 & $\mathrm{Y}$ & 34.4 & 103.2 \\
14 & $\mathrm{Mn}$ & 924 & 2772 & 29 & $\mathrm{Yb}$ & 3.15 & 9.45 \\
15 & $\mathrm{Mo}$ & 3.06 & 9.18 & 30 & $\mathrm{Zn}$ & 88.4 & 265.2 \\
\hline
\end{tabular}

Fig. 2 Scheme of experiment

degree of decrease of the integral index of biological state (IIBS) of the soil (Kolesnikov et al., 2014). IIBS was calculated based on the most sensitive and informative indicators of soil biological activity: total number of bacteria, abundance of the Azotobacter bacteria, catalase activity, cellulosolytic activity, to change of radish root length. The biological indicators were determined using conventional methods that are common for soil science and biology (Kazeev \&
Kolesnikov, 2012; Kazeev et al., 2016). The choice of these biological indicators is due to the following measurements:

\subsubsection{Measurement of the Total Number of Bacteria}

The total number of bacteria in the soil reflects the state of reducers in the ecosystem (Kolesnikov et al., 1999). The total number of bacteria in the soil was 
Table 2 Measurement of biological indicators of Haplic Chernozem condition

\begin{tabular}{|c|c|c|c|c|}
\hline No & Biological indicators & Methods & Measurement device & Measure unit \\
\hline 1 & Number of bacteria & $\begin{array}{l}\text { Luminescent microscopy with } \\
\text { alcidine orange }(1: 10,000) \text {, } \\
40 \times\end{array}$ & $\begin{array}{l}\text { Luminescent microscope Carl } \\
\text { Zeiss Axio Lab A1 }\end{array}$ & $10^{9}$ in $1 \mathrm{~g}$ of soil \\
\hline 2 & Azotobacter spp. abundance & $\begin{array}{l}\text { The method of fouling lumps on } \\
\text { the Ashby medium }\end{array}$ & $\begin{array}{l}\text { Abacterial air-box BAVnp-01- } \\
\text { "Laminar-S." - } 1.8\end{array}$ & $\%$ fouling lumps of soil \\
\hline 3 & Catalase activity & $\begin{array}{l}\text { By the rate of decomposition of } \\
\text { hydrogen peroxide }\end{array}$ & Volumetric device & $\mathrm{ml} \mathrm{O}_{2}$ per $1 \mathrm{~g}$ of soil in $1 \mathrm{~m}$ \\
\hline 4 & Cellulosolytic activity & $\begin{array}{l}\text { The rate of decomposition of } \\
\text { cellulose tissue in } 30 \text { days of } \\
\text { the experiment }\end{array}$ & Application method & $\%$ violation of tissue integrity \\
\hline 5 & Length of roots & $\begin{array}{l}\text { Change of length of roots radish } \\
\text { (Raphanus sativus L.) after } \\
7 \text { days of the experiment }\end{array}$ & $\begin{array}{l}\text { Growth chamber Binder KBW } \\
240\end{array}$ & $\%$ of control \\
\hline
\end{tabular}

determined by luminescence microscopy method considering the number of soil bacteria after staining with acridine orange (Kazeev \& Kolesnikov, 2012; Kazeev et al., 2016). After incubation, the soil was dried, and a soil suspension was prepared. On prepared glasses (defatted and sterilized), $10 \mu \mathrm{L}$ of soil suspension was placed, air-dried, and dried in a burner flame. Thereafter, the slides were stained with a solution of acridine orange $(1: 10,000)$ for $20 \mathrm{~min}$. The slides were washed to remove excess dye and dried in air. The preparations were viewed under a Carl Zeiss Axio Lab A1 microscope at a magnification of $\times 40(20$ bacterial cell counting fields).

\subsubsection{Measurement of Azotobacter spp. Abundance}

The Azotobacter spp. abundance is traditionally used as an indicator of chemical pollution of the soils (Val'kov et al. 1997). The Azotobacter spp. abundance was determined by the method of fouling lumps on Ashby medium. To assess the number of bacteria, Ashby's medium was prepared (Kazeev et al., 2016). The medium was poured into Petri dishes and lumps of moistened soil ( 25 pieces of soil per 1 dish) were stirred. These operations were performed in an abacterial air-box BAVnp-01 — "Laminar-S". The number of fouling lumps of soil was counted 14 days after the start of the experiment.

\subsubsection{Measurement of the Activity of Catalase}

The activity of catalase and dehydrogenases estimates the potential biological activity in soils. Activity of catalase is more sensitive to chemical pollution than other class of enzymes (Kolesnikov et al., 2000, Martinez et al., 2010)]. Catalase activity was determined according to Galstyan's (Galstyan, 1978). The enzyme activity was determined by the gasometric method by the rate of decomposition of $5 \%$ hydrogen peroxide after contact with the soil.

\subsubsection{Measurement of Cellulolytic Activity Cellulo-} lytic activity reflects the rate of mineralization of organic residues in the soil. To perform the analysis, at the beginning of the experiment, webs of cellulose tissue with a known weight were laid in the soil. The tissue was fixed on the plastic and after 30 days of the experiment, it was removed from the soil. They were taken out of the soil in lots, washed from the soil and dried. The intensity of cellulolytic activity was judged by the difference between the weight of the tissue flap before and after incubation. The result was expressed in $\%$ of the spread of the canvas.

\subsubsection{Measurement of Length of Roots of Radish}

Soil phytotoxicity was investigated by the length of roots in growth chamber Binder KBW 240 (Bab'eva \& Zenova 1989). To assess soil toxicity using plants, garden radish (Raphanus sativus L.) was used. Compared to other plant test objects, radish has a fast response to soil nutrients and moisture 
(Pandey, 2006; Nikolaeva \& Terekhova 2017). After incubation of the soil with chemical elements for 30 days, the soil was placed in a Petri dish. Radish seeds were planted in a Petri dish of the soil mass -25 seeds in Petri dishes in conditions of moisture $60 \%$ and temperature of $24-25{ }^{\circ} \mathrm{C}$ in growth chamber Binder KBW 240. After 7 days of the experiment, the radish was pulled out of the soil, the length of the radish roots was determined.

\subsection{Data Analysis}

To calculate IIBS, the value of each of the above indicators for control (in the unpolluted soil) was taken as $100 \%$, and the values in the remaining experiment options were expressed in relation to it as a percentage (in the contaminated soil). Then, the average value of the five selected indicators for each experiment option was determined. The value IIBS was expressed as a percentage of the control (to 100\%). The technique used allowed integrating the relative values of different indicators, the absolute values of which could not be integrated since they had different units of measurement.

The number of soil bacteria was determined by the luminescence microscopy method considering the number of soil bacteria after staining with acridine orange (Kazeev et al., 2016). The results were expressed in $10^{9}$ bacteria in $1 \mathrm{~g}$ of soil (Eq. (1)):

$\mathrm{M}=\frac{4 \times \mathrm{A} \times \mathrm{H} \times 10^{10}}{\mathrm{P}}$

where, $\mathrm{M}$ - number of cells per $1 \mathrm{~g}$ of soil; $\mathrm{A}-$ the average number of cells within one field of vision; $\mathrm{H}$ - dilution index; $\mathrm{P}$ - the area of the field of vision, $\mu \mathrm{m}^{2}$.

Integrated index of biological state of the soil is allowed to give an integral assessment of the condition of soils after any chemical pollution (Kolesnikov et al., 2013, 2019). For the calculation of IIBS, the value of each of the above indicators on the control (in unpolluted soil) was taken as $100 \%$. The percentages in other experimental variants (in polluted soil) were expressed as a percentage relative to control. For the IIBS condition, maximum value of each index $(100 \%)$ is chosen from array data, and in reference to this, value of this index was expressed for other variants of experiments by Eq. (2):

$\mathrm{B}_{1}=\frac{\mathrm{B}_{\mathrm{x}}}{\mathrm{B}_{\max }} \times 100 \%$

where $\mathrm{B}_{1}$ - is the relative score of the indicator; $\mathrm{B}_{\mathrm{x}}$ - the actual value of the indicator; $\mathrm{B}_{\max }-$ is the maximum value of the indicator.

The relative values of several mostly informative indices of soil biological condition such as the activity of catalase and cellulolytic activity, abundance of genus Azotobacter bacteria, total number of bacteria, and length of roots were summed. Thereafter, the average assessment point of studied indices was calculated for each variant by Eq. (3):

$\mathrm{B}=\frac{\mathrm{B}_{1}+\mathrm{B}_{2}+\ldots+\mathrm{B}_{\mathrm{n}}}{\mathrm{N}}$

where $\mathrm{B}$ - average estimated score of indicators; $\mathrm{B}_{1} \ldots \mathrm{B}_{\mathrm{n}}$ - the relative score of the indicator; $\mathrm{N}-$ is the number of indicators.

The integral index of the soil biological condition (IIBS) is calculated by Eq. (4):

$\mathrm{IIBS}=\frac{\mathrm{B}}{\mathrm{B}_{\max }} \times 100 \%$

where $\mathrm{B}$ - is the average estimated score of all indicators; $B_{\max }-$ is the maximum estimated score of all indicators.

During diagnostics of contamination value of each index in non-contaminated soil, it is taken as $100 \%$. With reference to its value of the same index in the contaminated soil is expressed in percent. The obtained value IIBS is expressed as a percentage concerning the control (to 100\%). The methodology used allows you to integrate the relative values of different indicators, which cannot be integrated since they have different units of measurement.

Determination of the hazard classes of elements was based on a methodology based on the percentage of change in the IIBS relative to control (Kolesnikov, 2002). When the indicator changes by $5-10 \%$, the metal/metalloid/non-metal is classified as low-toxic and low-hazard (III class), in case of violation of IIBS by $10-25 \%$, it is dangerous and toxic to the soil elements (II class), the most dangerous and toxic elements are referred to with a violation of the IIBS by more than $25 \%$ relative to the control (I class). To 
Table 3 Classes of soil pollutant by terms of their hazardous (GOST, 2008)

\begin{tabular}{lllll}
\hline No & Class of hazardous & Chemical elements & & \\
\cline { 3 - 5 } & & Metals & Metalloids & Non-metals \\
\hline I & High & $\mathrm{Cd}, \mathrm{Hg}, \mathrm{Pb}, \mathrm{Zn}$ & $\mathrm{As}$ & $\mathrm{Se}, \mathrm{F}$ \\
II & Moderate & $\mathrm{Co}, \mathrm{Ni}, \mathrm{Mo}, \mathrm{Cu}, \mathrm{Cr}$ & $\mathrm{B}, \mathrm{Sb}$ & - \\
III & Small & $\mathrm{Ba}, \mathrm{V}, \mathrm{W}, \mathrm{Mn}, \mathrm{Sr}$ & - & - \\
\hline
\end{tabular}

calculate hazard classes, ranks were built for ranking chemical elements according to the degree of their hazard to soil in concentration units (mg of an element/1 kg of soil) and per 1 atom (1 mol of an element $/ 1 \mathrm{~kg}$ of soil). The present hazard classes of chemical elements are presented in Table 3.

\subsection{Statistical Analyses}

To check the reliability of the results, an analysis of variance was carried out, followed by the determination of the least significant difference (LSD) at $\mathrm{p} \leq 0.05$. Data are means of triplicate biological samples. Statistical data processing was carried out using Statistica 12.0 and Python 3.6.5 Matpolib package. The correlation nonparametric Spearman's coefficient was calculated between the concentration of chemical elements and the average of biological indicators.

\section{Results}

\subsection{Ranking Potentially Toxic Elements by Ecotoxicity of Haplic Chernozem for Maximum Permissible Concentrations}

In the study of biological properties, soil contamination was carried out according to the MPC. This technique is used to assess the hazard and toxicity of elements in accordance with the accepted MPC. Study results made it possible to rank 30 chemical elements in terms of the degree of negative impact on the soil and distinguish three classes of elements in terms of their environmental hazard to the soil (Fig. 3). If MPC is taken as the unit content of the element in the soil: $\mathrm{Cr}>\mathrm{B}>\mathrm{Zn}>\mathrm{Se}>\mathrm{Ba} \geq \mathrm{As} \geq \mathrm{Sr}$ $=\mathrm{V} \geq \mathrm{Co}=\mathrm{F}=\mathrm{Mn} \geq \mathrm{Ni} \geq \mathrm{Cu}>\mathrm{Sc} \geq \mathrm{Pb}=\mathrm{Te} \geq \mathrm{Sn} \geq$ $\mathrm{Bi}=\mathrm{Cd}=\mathrm{W}=\mathrm{Nb}=\mathrm{Ga} \geq \mathrm{Ge} \geq \mathrm{Sb} \geq \mathrm{Ag}=\mathrm{Tl}=\mathrm{Yb} \geq$ $\mathrm{Hg} \geq \mathrm{Y}>\mathrm{Mo}$.

If the content of the element in the soil is expressed in MPC, then the most toxic element is $\mathrm{Cr}(53 \%$ below control) and the least toxic element is Mo. The MAC for chromium is 35 times higher than for Mo (Table 1).
Fig. 3 Ranking of PTEs according to the degree of decrease in soil IIBS values according to MPC, \% of control

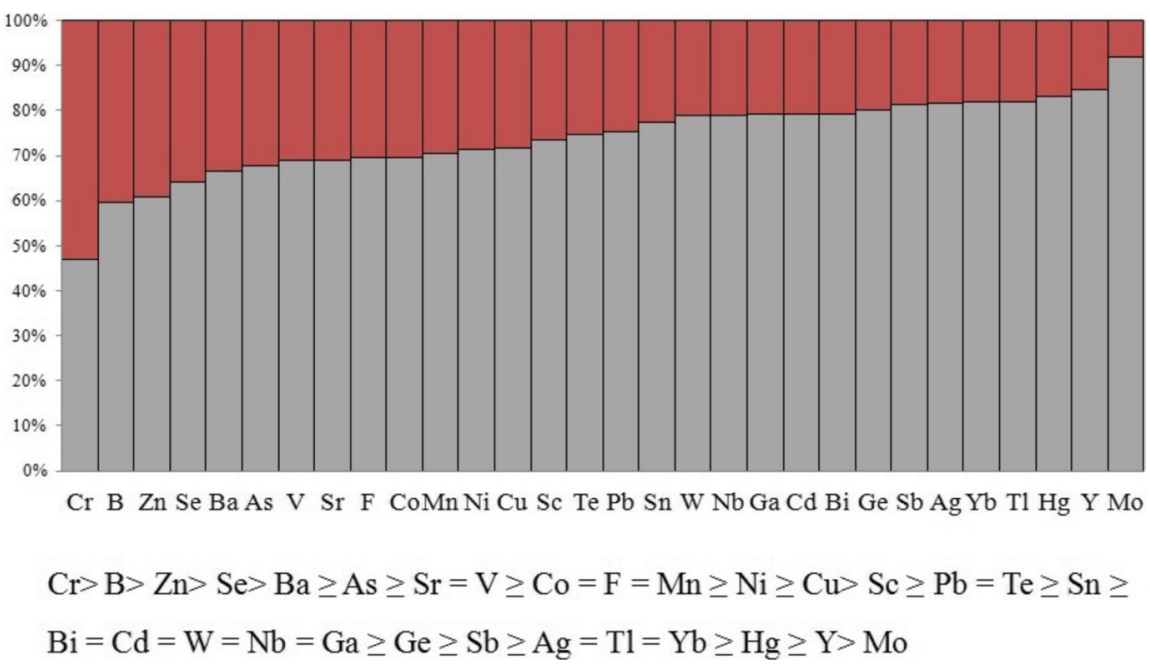


The toxic properties of chemical elements are manifested even after the introduction of 1 MPC of the element. At the same time, the degree of violation of biological indicators varies from 5 (Mo) to $53 \%$ (Cr). It should be noted that oxides of elements, which have low solubility in water, and, consequently, low mobility in the soil, were introduced into the soil. Water-soluble salts of the investigated elements would have a more toxic effect. According to the compiled toxicity series, chemical elements cannot be ranked by hazard classes, since the concentrations used for the experiment, expressed in 1 MPC, are not equivalent for different elements.

\subsection{Ranking Potentially Toxic Elements by Ecotoxicity of Haplic Chernozem of Concentration Units (in $\mathrm{mg} / \mathrm{kg}$ )}

After calculating the hazard rank of chemical elements according to MPC, a comparison was made of the hazard and toxicity of the elements in terms of concentration, expressed in $\mathrm{mg}$ of an element per $1 \mathrm{~kg}$ of soil (Fig. 4). According to the results obtained, a number of ranking elements were compiled according to the degree of danger: $\mathrm{Te}>\mathrm{Se} \geq \mathrm{Ag} \geq \mathrm{Cr}>\mathrm{Bi}=\mathrm{Ge}$ $\geq \mathrm{Sn}=\mathrm{Tl} \geq \mathrm{Hg} \geq \mathrm{Yb}=\mathrm{W} \geq \mathrm{Cd}>\mathrm{As}=\mathrm{Co}=\mathrm{Sc}=\mathrm{Sb} \geq \mathrm{Cu} \geq \mathrm{Ni} \geq$ $\mathrm{B}=\mathrm{Nb}=\mathrm{Pb} \geq \mathrm{Ga}>\mathrm{Sr}=\mathrm{Y} \geq \mathrm{Mo} \geq \mathrm{Zn} \geq \mathrm{V} \geq \mathrm{Ba} \geq \mathrm{Mn} \geq \mathrm{F}$.

The greatest toxic effect on the biological functions of the soil was exerted by Te (metalloid), Se (nonmetal), $\mathrm{Ag}$ and $\mathrm{Cr}$ (metals) - 60, 34, 33, and $31 \%$, respectively. The least negative impacts were on $\mathrm{F}$ (non-metal) and $\mathrm{Ba}$ and $\mathrm{Mn}$ (metal).

The elements with a high degree of toxicity (violation of IIBS by more than 25\%) include tellurium, selenium, silver, chromium, germanium, and bismuth. These elements belong to metals ( $\mathrm{Cr}, \mathrm{Ag}, \mathrm{Bi}$ ), metalloids (Te, $\mathrm{Ge}$ ), and nonmetals (Se). The toxicity of selenium and chromium was previously confirmed by Dutch researchers (Crommentuijn et al., 1997). The rest of the elements were previously classified as hazard II and III classes. In GOST 17.4.1.02-83, chromium is also classified as hazard II class (GOST, 2008). The rest of the elements are considered low-hazard and also were not assigned to I class. As shown in our study, their toxicity is underestimated. Low-toxic elements include strontium, yttrium, molybdenum, zinc, tungsten, barium, and manganese. Such indicators of toxicity are due to the chemical properties of the elements: solubility in acids and alkalis, melting point, and others, although some elements differing diametrically in toxicity are in the same group, like chromium and molybdenum. According to the Periodic Table of D.I. Mendeleev, these elements are in group VIb, but in periods 4 and 6 . They exhibit different physicochemical properties: a chromium element with a high melting point (melting point $=1890^{\circ} \mathrm{C}$ ), but easily oxidized in air from $\mathrm{Cr}^{+6}$ to $\mathrm{Cr}^{+3}$, and molybdenum is very refractory (melting point $=2615^{\circ} \mathrm{C}$ ) and
Fig. 4 Ranking of PTEs (in the calculation of $1 \mathrm{mg}$ of an element per $1 \mathrm{~kg}$ of soil) according to the degree of decrease in soil IIBS values by concentration, $\%$ of control

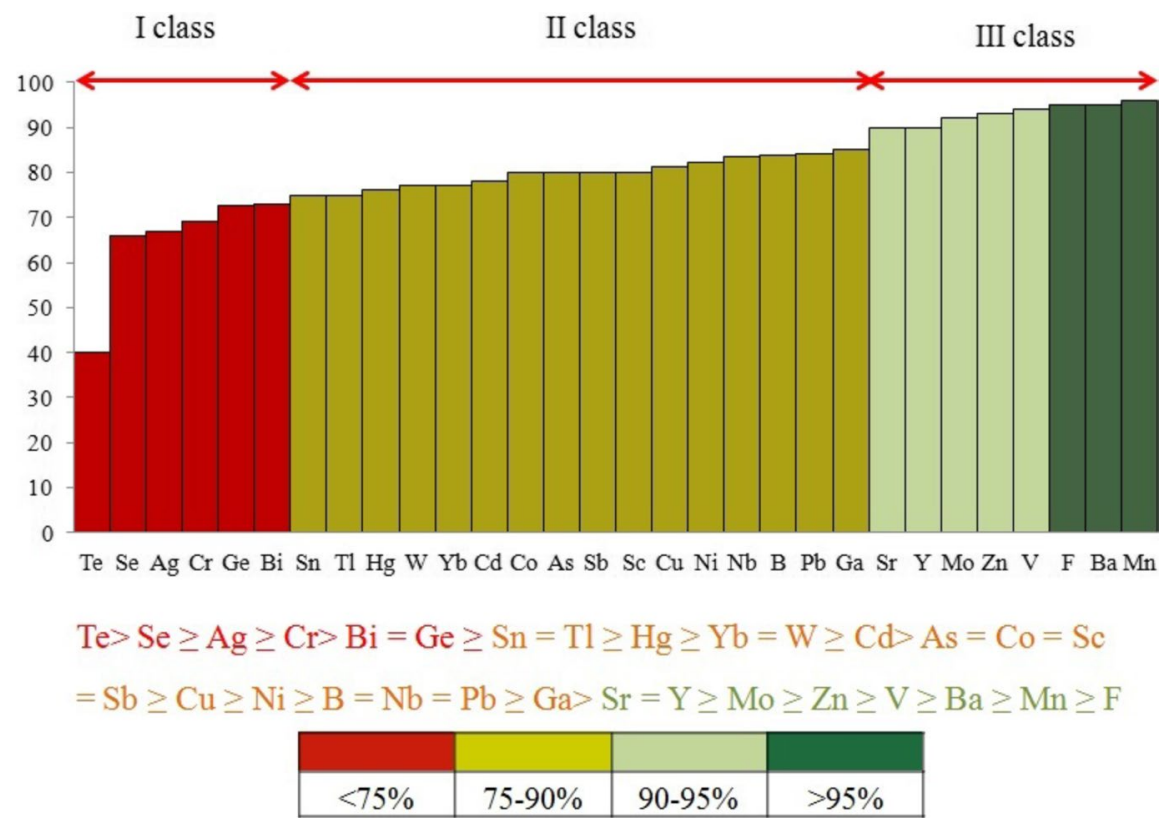


poorly oxidized by acids and alkalis. The rest of the low-toxic elements (Sr, Y, Zn, V, Ba, Mn, F) have a high background content in the soil from $88.4 \mathrm{mg} / \mathrm{kg}$ (Zn) to $924 \mathrm{mg} / \mathrm{kg}(\mathrm{Mn})$. Taking into account the buffer capacity of Haplic Chernozem, even an excess of the background by 3 or more orders of magnitude did not have a toxic effect on the ecological state of the soil.

\subsection{Ranking Potentially Toxic Elements by Ecotoxicity of Haplic Chernozem of Concentration Units (in $\mathrm{mol} / \mathrm{kg}$ )}

The concentration of PTEs in terms of 1 atom in relation to $1 \mathrm{~kg}$ of soil is of interest from an empirical point of view: such an estimate is of scientific value, which makes it possible to evaluate each specific atom in relation to the volume of the soil. The ranking and toxicity of chemical elements per atom is shown in Fig. 5. The following series of ecotoxicity of the chemical elements (metals, metalloids and nonmetals) were obtained (mol $/ \mathrm{kg}$ ). Rating of elements: $\mathrm{Te} \geq \mathrm{Se}>\mathrm{Ag}>\mathrm{Bi} \geq \mathrm{Tl} \geq \mathrm{Cr} \geq \mathrm{Hg} \geq \mathrm{W}>\mathrm{Cd} \geq \mathrm{Ge}=\mathrm{Yb}$ $\geq \mathrm{Cu}=\mathrm{Pb}=\mathrm{Sn} \geq \mathrm{Ni}>\mathrm{Sb} \geq \mathrm{Co}=\mathrm{Zn} \geq \mathrm{Sc} \geq \mathrm{B}=\mathrm{Nb}=\mathrm{S}$ $\mathrm{r} \geq \mathrm{As}=\mathrm{Ga} \geq \mathrm{Ba}=\mathrm{Mo}=\mathrm{V} \geq \mathrm{Mn}>\mathrm{F} \geq \mathrm{Y}$.

If the content of the PTEs in the soil is expressed in $\mathrm{mol} / \mathrm{kg}$, as the number of atoms per unit mass of the soil, then the most toxic elements are also Te, Se, and Ag - 70, 56, and 33\% of control. The lowest toxicity corresponds to metals (Mn, Y) and nonmetal (F). It should be noted that in case of contamination of soil with $\mathrm{Te}, \mathrm{Se}, \mathrm{Ag}, \mathrm{Bi}, \mathrm{Ge}$, and $\mathrm{Tl}$, no statistically significant effect of "hormesis" (pollutant stimulating effect) was observed at any single dose or biological parameter, unlike the vast majority of metals and metalloids that are considered very dangerous, such as $\mathrm{Hg}, \mathrm{Cd}, \mathrm{Pb}, \mathrm{Cr}, \mathrm{Cu}, \mathrm{Zn}$, etc.

\subsection{Ranking Potentially Toxic Elements for Class of Hazardous}

In terms of soils and terrestrial ecosystems as a whole (since the residence of terrestrial ecosystem to chemical pollution depends almost entirely on soil residence), it is advisable to use its own hazard classes. For this purpose, it is possible to use the number of elements obtained in the present study, where content unit of the element in the soil is $\mathrm{mg} / \mathrm{kg}$ (Fig. 4).

According to the accepted classification by hazard classes (Kolesnikov et al., 2002), chemical elements can be classified as follows. The most dangerous elements (I class) include 3 metals (Ag, Cr, Bi), 2 metalloids (Ge, Te) and 1 nonmetal (Se). For II class of hazard, the ranking includes 13 metals $(\mathrm{Sn}, \mathrm{Tl}, \mathrm{Hg}$, $\mathrm{Yb}, \mathrm{W}, \mathrm{Cd}, \mathrm{Co}, \mathrm{Sc}, \mathrm{Cu}, \mathrm{Ni}, \mathrm{Nb}, \mathrm{Pb}, \mathrm{Ga}), 3$ metalloids (As, B, Sb). For III class of hazard corresponds to 7
Fig. 5 Ranking of PTEs (per 1 atom in $1 \mathrm{~kg}$ of soil) according to the degree of decrease in IIBS values, $\%$ of control

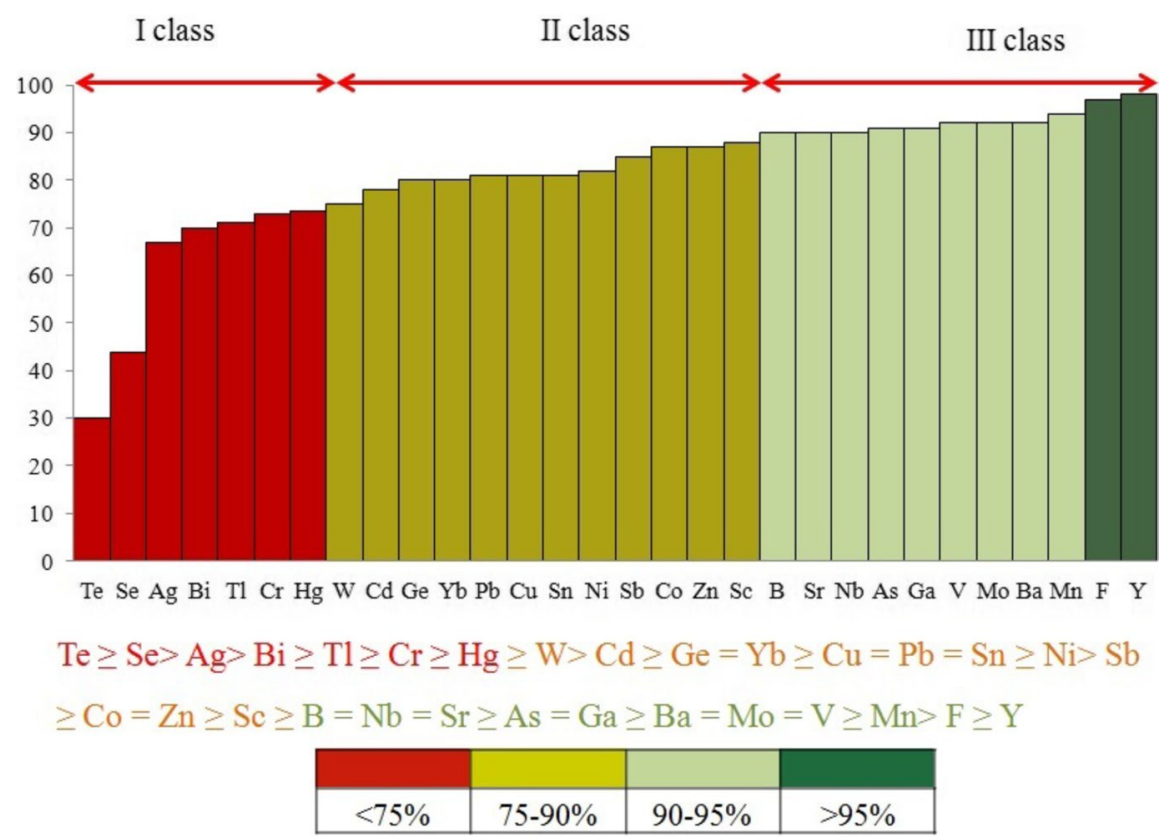


Table 4 Classes of chemical elements in terms of their environmental hazard for Haplic Chernozem

\begin{tabular}{lllll}
\hline No & Class of hazardous & Chemical PTEs & \\
\cline { 3 - 5 } & & Metals & Metalloids & Nonmetals \\
\hline I & High & $\mathrm{Ag}, \mathrm{Cr}, \mathrm{Bi}$ & $\mathrm{Ge}, \mathrm{Te}$ & $\mathrm{Se}$ \\
II & Moderate & $\mathrm{Sn}, \mathrm{Tl}, \mathrm{Hg}, \mathrm{Yb}, \mathrm{W}, \mathrm{Cd}, \mathrm{Co}$, & $\mathrm{As}, \mathrm{B}, \mathrm{Sb}$ & - \\
& & $\mathrm{Sc}, \mathrm{Cu}, \mathrm{Ni}, \mathrm{Nb}, \mathrm{Pb}, \mathrm{Ga}$ & & \multirow{2}{*}{ F } \\
III & Small & $\mathrm{Sr}, \mathrm{Y}, \mathrm{Mo}, \mathrm{Zn}, \mathrm{V}, \mathrm{Ba}, \mathrm{Mn}$ & - & \\
\hline
\end{tabular}

Fig. 6 Average ranking of PTEs for $\mathrm{mg} / \mathrm{kg}$ and $\mathrm{mol} / \mathrm{kg}$ of Haplic Chernozem

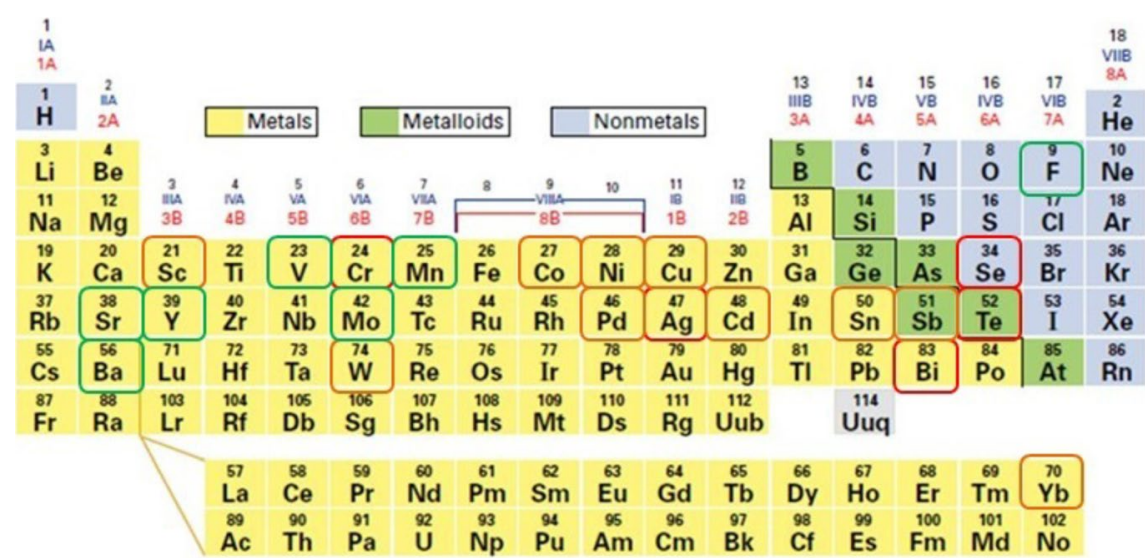

Ranking of metal, metalloids and nonmetals for hazard classes

\begin{tabular}{|c|c|c|c|c|c|c|c|c|c|c|c|}
\hline I & $\mathrm{Te}$ & $\mathrm{Se}$ & $\mathrm{Ag}$ & $\mathrm{Cr}$ & $\mathrm{Bi}$ & \multicolumn{5}{|c|}{} \\
\hline & II & $\mathrm{Sn}$ & $\mathrm{Yb}$ & $\mathrm{W}$ & $\mathrm{Cd}$ & $\mathrm{Co}$ & $\mathrm{Sb}$ & $\mathrm{Sc}$ & $\mathrm{Cu}$ & $\mathrm{Ni}$ & $\mathrm{Pb}$ \\
\hline & III & $\mathrm{Sr}$ & $\mathrm{Y}$ & $\mathrm{Mo}$ & $\mathrm{V}$ & $\mathrm{F}$ & $\mathrm{Ba}$ & $\mathrm{Mn}$ & & &
\end{tabular}

metals (Sr, Y, Mo, Zn, V, Ba, Mn) and 1 nonmetal (F) (Table 4).

Comparison of the series of toxicity of elements by $\mathrm{mg} / \mathrm{kg}$ (Fig. 4) and by moles (Fig. 5) made it possible to establish a high percentage of coincidence of elements: in class I, there was a coincidence of 5 out of 6 , in II class -10 out of 16 , in III class -7 out of 11 (Fig. 6).

Thus, the summary series of toxicity by hazard class is as follows: I class: $\mathrm{Te}, \mathrm{Se}, \mathrm{Ag}, \mathrm{Cr}, \mathrm{Bi}$; II class: $\mathrm{Sn}, \mathrm{Yb}, \mathrm{W}, \mathrm{Cd}, \mathrm{Co}, \mathrm{Sb}, \mathrm{Sc}, \mathrm{Cu}, \mathrm{Ni}, \mathrm{Pb}$; III class: Sr, Y, Mo, V, F, Ba, Mn.

The presented generalized series can be compared with the concentration series in $\mathrm{mg} / \mathrm{kg}$. It has been established that the ecotoxicity of chemical elements is not associated with their belonging to the group of metals, metalloids, and non-metals. Metals, metalloids, and non-metals are represented in each hazard class.

\section{Discussion}

The ecotoxicity of pollutants is manifested earlier than the three backgrounds (Kolesnikov et al., 2008a, 2009, 2011, 2014, 2019, 2020, 2021; Popovich \& Kolesnikov 2005). This applies to all studied elements. Previously, it was believed that before the concentration of pollutant in the soil is less than four backgrounds, its toxicity is not manifested. It should be noted that oxides of the elements were introduced into the soil with low solubility in water and, consequently, low mobility in soil. Watersoluble salts of the investigated elements would have higher toxic effect. Moreover, the study was 
conducted on Haplic Chernozem that is characterized by high buffer capacity with respect to chemical pollution. In soils with a lighter granulometric composition, less organic matter, and more acidic, the ecotoxicity of most pollutants will be even higher (Kolesnikov et al., 2020, 2021; Guney et al., 2020; Minnikova et al., 2017). According to the degree of inhibition of biological activity in Haplic Chernozem, the studied metals formed the following series: $\mathrm{Cd}>\mathrm{Pb}>\mathrm{Zn}>\mathrm{Cu}$ (Gromakova et al., 2017). The physicochemical properties of soils and technogenic load affect their biological activity. Close correlations are revealed between the activity of dehydrogenases in chernozem (Chernozems Calcic), meadow-chernozemic soil (Phaeozems Haplic) and alluvial soils (Fluvisols Umbric) and the $\mathrm{pH}$ value and the contents of carbonates and phosphate ions (Minnikova et al., 2017).

The highest toxicity (I class) is possessed by $\mathrm{Te}$, $\mathrm{Se}, \mathrm{Ag}, \mathrm{Cr}, \mathrm{Bi}$. These elements are referred to as nonmetals (Se), metalloids (Te), and metals (Ag, Cr, Bi). However, at present, their high toxicity for soil and human health has been reliably established for Ag, $\mathrm{Cr}$, and Se. According to the Science Direct website (https://www.sciencedirect.com/search), it was established that over the past 3 years (2019-2021), 6713, 6384 , and 3052 articles were written on the assessment of the toxicity of $\mathrm{Cr}, \mathrm{Ag}$, and $\mathrm{Se}$, respectively for soils. At the same time, other elements, such as Te and $\mathrm{Bi}$, are of several times less interest among users of 877 and 308 articles on the toxic effect of $\mathrm{Bi}$ and Te on the soil over the same period. The ecotoxicity of chromium in terms of biological indicators was assessed according to several works (Ahmad et al., 2021; Fan et al. 2021a, 2021b; Kolesnikov et al., $2009,2014)$. According to the data of previous studies on the toxicity of $\mathrm{Ag}$ and $\mathrm{Bi}$, its toxic effect on ordinary chernozem was proved even at a dose of 4.4 and $8.5 \mathrm{mg} / \mathrm{kg}$ (Kolesnikov et al., 2020; Sudina et al., 2021). The reasons for the negative effect of tellurium on the biological properties of soils, as well as in selenium, are expressed by inhibition of soil enzymes and a decrease in the permeability of biological membranes, followed by disruption in metabolism (Kolesnikov, 2008b, 2019).

A working hypothesis when comparing MPC, chemical element concentrations in $\mathrm{mg} / \mathrm{kg}$ and moles per $1 \mathrm{~kg}$ of soil, different sequences of toxicity of chemical elements were found. In this work, it has been established that the use of MPCs to assess several toxicity of metals and hazard classes of elements is unacceptable, since the initial concentrations of elements are incomparable. Comparison of metals, metalloids, and nonmetals with a concentration of $1 \mathrm{mg}$ in $1 \mathrm{~kg}$ of soil, as well as molar concentration (per 1 atom in $1 \mathrm{~kg}$ of soil) made it possible to rank the elements according to toxicity classes. This series does not coincide with the previously proposed series (Kolesnikov et al., 2010; Vodyanitskiy, 2012), which is due to the concentration of elements and the knowledge of the impact on the biological properties of the soil.

In the future, to continue research: to use of a wider range of biological indicators (enzymes of different classes, zoo- and phytoindicators) for the calculation of IIBS; to assess changes in toxicity and hazard classes with increasing concentrations and changes in the forms of chemical compounds elements; to rank chemical elements by classes lanthanoids, actinides, alkaline earth metals; to allocate hazard classes separately among metals, metalloids and non-metals; to study the toxicity of chemical elements for soils of different buffering capacity and resistance to pollution.

\section{Conclusion}

Comparative assessment of ecotoxicity and rating of 30 heavy metals, metalloids and non-metals show that in terms of negative effect on biological indexes of condition of Haplic Chernozem, the most toxic PTE Te and least PTE-F. The ecotoxicity of $\mathrm{Te}, \mathrm{Se}, \mathrm{Ag}, \mathrm{Bi}, \mathrm{Ge}, \mathrm{Tl}$ is underestimated. In case of contamination of soil with $\mathrm{Te}, \mathrm{Se}, \mathrm{Ag}, \mathrm{Bi}, \mathrm{Ge}, \mathrm{Tl}$, no statistically significant effect of hormesis (pollutant stimulating effect) was observed at any single dose or biological parameter, unlike most heavy metals and metalloids that are considered very dangerous, such as $\mathrm{Hg}, \mathrm{Cd}, \mathrm{Pb}, \mathrm{Cr}, \mathrm{Cu}, \mathrm{Zn}$, etc. According to the influence on the soil condition, the PTEs are classified according to the hazard classes, which do not fully coincide with the hazard classes developed in relation to human health. It is proposed to distinguish three classes of environmental hazards of the elements in relation to the soil. In the future, studies of higher concentrations of chemical 
elements, assessment of the stability of different types of soils, the study of the toxicity of rare earth elements, the series of lanthanoids and actinides, a wide range of nonmetals.

Author contribution TM (Ph.D), YA (Ph.D, assistant of professor), NE (Ph.D. Student) has done all the experiments. SK (Professor) and KK (Professor) has drafted the manuscript and TM (Ph.D) is the corresponding author who has supervised the work and prepared all the probable improvements in the manuscript.

Funding This research was financially supported the President of the Russian Federation (SSc-2511.2020.11), Ministry of Science and Higher Education of the Russian Federation within the framework of the state task in the field of scientific activity (Southern Federal University, no. 0852-2020-0029), supported by the "Priority 2030" program of the Ministry of Science and Education of the Russian Federation, project no. SP02/S4_0708 Priority_01/SP02/S4_0706 Priority_01.

Data availability All data are fully available without restriction.

\section{Declarations}

Conflict of interest The authors declare no competing interests.

\section{References}

Abramenko, I. P., Novoselskaya, L. A., Revunov, R. V., \& Chumakova, V. N. (2019). Ways to increase the socio-ecological and economic efficiency of regional environmental management in modern conditions (based on materials from the Rostov region). Melioration and Hydraulic Engineering, 3(35), 173-187. https://doi.org/10.31774/ 2222-1816-2019-3-173-187

Ahmad, T., Ahmad, K., Khan, Z. I., Munir, Z., Khalofah, A., Al-Qthanin, R. N., Alsubeie, M. S., Alamri, S., Hashem, M., Farooq, S., Maqbool, M. M., Hashim, S., \& Wang, Y.-F. (2021). Chromium accumulation in soil, water and forage samples in automobile emission area. Saudi Journal of Biological Sciences, 28(6), 3517-3522. https://doi. org/10.1016/j.sjbs.2021.03.020

Aristarkhov, A., Lunev, M., \& Pavlikhina, A. (2016). Ecological and agrochemical assessment of the state of arable soils in Russia by the content of mobile forms of heavy metals in them. International Agricultural Journal., 6, 42-48.

Aueviriyavit, S., Phummiratch, D., \& Maniratanachote, R. (2014). Mechanistic study on the biological effects of silver and gold nanoparticles in CaCO-2 cells - induction of the Nrf2/HO-1 pathway by high concentrations of silver nanoparticles. Toxicology Letters., 224(1), 73-83.
Azarenko (Myasnikova), M.A. 2014. Comparative characteristics of chernozems of specially protected natural areas of the Rostov region. Proceedings of higher educational institutions. North Caucasian region. Series: Natural Sciences. 2 (180). 63-66.

Azarenko (Myasnikova), M. A., Kazeev, K. S. H., Yermolayeva, O. Y., \& Kolesnikov, S. I. (2020). Changes in the plant cover and biological properties of chernozems in the postagrogenic period. Eurasian Soil Science., 53(11), 1645-1654.

Bab'eva, M.A., Zenova, N.K., 1989. Soil biology. Moscow State University Publishing House 336.

Baceva, K. A., Stafilov, T., \& Matevski, V. (2014). Bioaccumulation of heavy metals by endemic Viola species from the soil in the vicinity of the As-Sb-Tl mine "all char" Republic of Macedonia. Int J Phytoremediat., 16, 347-365.

Benini, S., Cianci, M., Mazzei, L., \& Ciurli, S. (2014). Fluoride inhibition of Sporosarcinapasteurii urease: Structure and thermodynamics. Journal Biological Inorganic Chemistry., 19, 1243-1261.

Benn, T., Cavanagh, B., Histovski, K., Posner, J. D., \& Westerhoff, P. (2010). The release of nanosilver from consumer products used in the home. Journal of Environmental Quality., 39(6), 1875-1882.

Cannas, D., Loi, E., Serra, M., Firinu, D., Valera, P., \& Zavattari, P. (2020). Relevance of essential trace elements in nutrition and drinking water for human health and autoimmune disease risk. Nutrients, 12, 2074.

Chen, T. J., \& Lin, C. H. (2011). Germanium: Environmental pollution and health effects. Encyclopedia of Environmental Health, 16, 927-933.

Chen, Y. W., Li, L., D’Ulivo, A., \& Belzile, N. (2006). Extraction and determination of elemental selenium in sediments-a comparative study. Anal Chimica Acta, 577(1), $126-133$.

Cheshev, A. S. (2015). Analysis of the qualitative state of the land fund of the Rostov region and the prospects for its use. Economics and Ecology of Territorial Entities, 1, 5-15.

Crommentuijn, T., Polder, M.D., Van de Plassche, E.J., 1997. Maximum permissible concentrations and negligible concentrations for metals, taking background concentrations into account (RIVM Report 601501001) Bilthoven, Netherlands. 260.

Domingo, J. L., García, F., Nadal, M., \& Schuhmacher, M. (2017). Autopsy tissues as biological monitors of human exposure to environmental pollutants. A case study: Concentrations of metals and PCDD/Fs in subjects living near a hazardous waste incinerator. Environmental Research, 154, 269-274.

Domingo, J. L., \& Marquès, M. (2021). The effects of some essential and toxic metals/metalloids in COVID-19: A review. Food and Chemical Toxicology, 152, 112161.

Druzhinin, A. V., \& Karelina, E. V. (2008). The main types of industrial silver deposits. Bulletin of RUDN: Engineering Research Series., 1, 35-41.

Ellrich, J., Hirner, A., \& Stark, H. (1985). Distribution of trace elements in crude oils from southern Germany. Chemical Geology, 48, 313-323.

Engwa, G. A., Ferdinand, P. U., Nwalo, F. N., \& Unachukwu, M. N. (2019). Mechanism and health effects of heavy 
metal toxicity in humans. Mechanism and Health Effects of Heavy Metal Toxicity in Humans. https://doi.org/10. 5772/intechopen.82511

Environmental protection and rational use of natural resources. 2019-2030 Approved by the Decree of the Government of the Rostov Region dated 15.10.2018 No. 638 Available online November, 232021

Esplugas, R., Mari, M., Marquès, M., Schuhmacher, M., Domingo, J. L., \& Nadal, M. (2019). Biomonitoring of trace elements in hair of schoolchildren living near a hazardous waste incinerator-A 20 years follow-up. Toxics, 7, 52 .

Fan, B., Tang, M., Yao, L., Zhang, A., Yin, H., Yang, W., Ma, Z., Xiang, W., \& Bao, Z. (2021a). Germanium fractions in typical paddy soil and its interaction with humic substances. Environmental Science and Pollution Research, 28, 9670-9681.

Fan, C., Qian, J., Yang, Y., Sun, H., Song, J., \& Fan, Y. (2021b). Green ceramsite production via calcination of chromium contaminated soil and the toxic $\mathrm{Cr}(\mathrm{VI})$ immobilization mechanisms. Journal of Cleaner Production, 315, 128204. https://doi.org/10.1016/j.jclepro.2021.128204

Fedele, D., De Francesco, A., Riso, S., \& Collo, A. (2021). Obesity, malnutrition, and trace element deficiency in the coronavirus disease (COVID-19) pandemic: an overview. Nutrition, 81, 111016.

Ferronato, C., Carbone, S., Vianello, G., \& Antisari, L. V. (2016). Thallium toxicity in Mediterranean horticultural crops (Fragaria vesca L., Mentha pulegium L., Ocimum basilicum L.). Water Air and Soil Pollution., 227(10), 375.

Galstyan, A. S. (1978). Unification of methods for studying the activity of soil enzymes. Eurasian Soil Science, 2, 107-114.

Gomathi, M., Rajkumar, P. V., Prakasam, A., \& Ravichandran, K. (2017). Green synthesis of silver nanoparticles using Datura stramonium leaf extract and assessment of their antibacterial activity. Resource-Efficient Technologies., 3, 280-284.

Gorbov, S.N., Bezuglova, O.S., Varduni, T.V., Gorovtsov, A.V., Tagiverdiev, S.S., Gildebrant, Yu. Genotoxicity and heavy metal pollution of natural and anthropogenically transformed soils of Rostov-on Don. Soil Science. 2015. 15191529. doi: https://doi.org/10.7868/S0032180X15120084.

GOST 17.4.1.02-83. 2008. Nature protection. Soils. Classification of chemicals for pollution control. Moscow: Standartinform,

Gromakova, N., Mandzhieva, S. S., Minkina, T. M., Birukova, O., Kolesnikov, S. I., Motuzova, G., Chaplygin, V. A., Barsova, N., Zamulina, I. V., Sushkova, S. N., \& Litvinov, Y. (2017). Effect of heavy metals on the enzymatic activity of Haplic Chernozem under model experimental conditions. Journal of Biological Sciences, 17, 143-150. https://doi.org/10.3844/ojbsci.2017.143.150

Guney, M., Yagofarova, A., Yapiyev, V., Schönbach, C., Kim, J. R., \& Inglezakis, V. J. (2020). Distribution of potentially toxic soil elements along a transect across Kazakhstan. Geoderma Regional., 21, 00281. https://doi.org/10. 1016/j.geodrs.2020.e00281

Guo, J. C., Yinglan, L., Zhuanxi, F., Hongda, C., Zhenfang, W., Dapeng, X., Feifei, Y., \& Changzhou, Y. (2018). Distribution, fractions, and potential release of thallium in acidic soils nearby a waste copper mining site from southern China. Environmental Science and Pollution Research., 25, 1-9.

Hoang, B. X., \& Han, B. (2020). A possible application of hinokitiol as a natural zinc ionophore and anti-infective agent for the prevention and treatment of COVID-19 and viral infections. Med Hypotheses, 145, 110333.

https://www.donnews.ru/V-minprirody-Rostovskoy-oblas ti-nazvali-samye-gryaznye-goroda-v-regione_116602 Available online November December, 231, 2021

https://www.sciencedirect.com/search Available Online December, 17, 2021

Huang, X., Li, N., Wu, Q., Long, J., Luo, D., Zhang, P., Yao, Y., Huang, X., Li, D., Lu, Y., \& Liang, J. (2016). Risk assessment and vertical distribution of thallium in paddy soils and uptake in rice plants irrigated with acid mine drainage. Environmental Science and Pollution Research International, 23, 24912-24921.

Il'in, V. B., \& Konarbaeva, G. A. (2000). Thallium in soils of the South of Western Siberia. Pochvovedenie, 6, 701-705.

Index EP 2018. EPI report. Yale University. https://epi.envir ocenter.yale.edu/2018-epi-report/ introduction. Accessed 17 Oct 2018

IUSS Working Group WRB. 2015. World Reference Base for Soil Resources 2014, update 2015. International soil classification system for naming soils and creating legends for soil maps. World Soil Resources Reports No. 106.

Jones, K. C., Davies, B. E., \& Peterson, P. J. (1986). Silver in Welsh soils: Physical and chemical distribution studies. Geoderma, 37, 157-174.

Kabata-Pendias, A. 2010. Trace elements in soils and plants. 4th Edition. Boca Raton, FL: Crc Press, 2010. 548.

Kaiser, S., Wagner, S., Moschner, C., Funke, C., \& Wiche, O. (2020). Accumulation of germanium $(\mathrm{Ge})$ in plant tissues of grasses is not solely driven by its incorporation in phytoliths. Biogeochemistry, 148, 49-68.

Kasimov, N. S., \& Vlasov, D. V. (2012). Technophilicity of chemical elements at the beginning of the XXI century. Bulletin of Moscow University Ser. 5. Geography, 1, $15-22$.

Kaya, E. D., Söyüt, H., \& Beydemir, S. (2015). The toxicological impacts of some heavy metals on carbonic anhydrase from gilthead sea bream (Sparus aurata) gills. Environmental Toxicology and Pharmacology, 39, 825-832.

Kazadaev, A.A., Bulysheva, N.I., Kremenitsa, A.M., Kazeev, K.SH., Kolesnikov, S.I., Abramova, T.I., 2004. Some biological features of the common lower Don chernozem (Virgin area of the "Persianovskaya Steppe" SPNA). Proceedings of higher educational institutions. North Caucasian region. Natural Sciences. 4, 91-101.

Kazeev, K. S., \& Kolesnikov, S. I. (2012). Soil biodiagnostics: Methodology and research methods (p. 260). Publisher of Southern Federal University.

Kazeev, K.S., Kolesnikov, S.I., Akimenko, Yu.V., Dadenko, E.V., 2016. Metody biodiagnostiki nazemnyh ekosistem. Rostov-na-Donu: Izdatel'stvo YuFU. 356.

Kizilshtein, L.Ya., Levchenko, S.V., 2003. Impurity elements and environmental problems of coal energy. Teploenergetika. 14-19. 
Klimov, P. V. (2018). Ecological and hygienic assessment of atmospheric air pollution in the cities of the Rostov region. Safety of technogenic and natural systems, 1-2, 107-113.

Kolesnikov, S., Minnikova, T., Minkina, T., Rajput, V. D., Tsepina, N., Kazeev, K., Zhadobin, A., Nevedomaya, E., Ter-Misakyants, T., Akimenko, Y., Mandzhieva, S., Sushkova, S., Ranjan, A., \& Asylbaev, I. (2021). Toxic effects of thallium on biological indicators of Haplic Chernozem health: A case study. Environments, 8, 119. https://doi.org/10.3390/environments8110119

Kolesnikov, S. I. (2019). Impact of contamination with tellurium on biological properties of ordinary chernozem. Soil and Sediment Contamination., 28(8), 792-800. https://doi.org/10.1080/15320383.2019.1666793

Kolesnikov S.I., Tsepina N.I., Sudina L.V, Minnikova T.V., Kazeev K.Sh., Akimenko Yu.V., 2020. Silver ecotoxicity estimation by the soil state biological indicators. Applied and Environmental Soil Science, 1-9.

Kolesnikov, S., Zharkova, M., Kazeev, K., Kutuzova, I., Samokhvalova, L., Naleta, E., \& Zubkov, D. (2014). Ecotoxicity assessment of heavy metals and crude oil based on biological characteristics of Chernozem. Russian Journal of Ecology, 3, 157-166.

Kolesnikov, S., Zharkova, M., Kazeev, K., Kutuzova, I., Samokhvalova, L., Naleta, E., \& Zubkov, D. (2014). Ecotoxicity assessment of heavy metals and crude oil based on biological characteristics of Chernozem. Russian Journal of Ecology, 3, 157-166.

Kolesnikov, S. I., Evreinova, A. V., Kazeev, KSh., \& Val'kov, V.F. (2009). Changes in the ecological and biological properties of ordinary Chernozems polluted by heavy metals of the second hazard class (Mo Co, Cr, and Ni). Eurasian Soil Science., 42(8), 936-942.

Kolesnikov, S. I., Kazeev, KSh., Timoshenko, A. N., Akimenko, Yu. V., \& Myasnikova, M. A. (2019). Ecotoxicity of copper, nickel, and zinc nanoparticles assessment on the basis of biological indicators of Chernozems. Eurasian Soil Science, 52(8), 982-987.

Kolesnikov, S. I., Kazeev, K. S. H., Val'kov, V. F., \& Ponomareva, S. V. (2010). Ranking of chemical elements according to their ecological hazard for soil. Russian Agricultural Sciences, 36(1), 32-34.

Kolesnikov, S. I., Kazeev, KSh., \& Val'kov, V. F. (1999). The effect of heavy metal contamination on the microbial system in chernozem. Eurasian Soil Science, 32(4), 459-465.

Kolesnikov, S. I., Kazeev, KSh., \& Val'kov, V. F. (2000). Effects of heavy metal pollution on the ecological and biological characteristics of common chernozem. Russian Journal of Ecology, 31(3), 174-181.

Kolesnikov, S. I., Ponomareva, S. V., Denisova, T. V., Kazeev, K. S., \& Val'kov V.F.,. (2011). Biological properties of ordinary chernozem contaminated with $\mathrm{Ba}, \mathrm{Mn}, \mathrm{Sb}, \mathrm{Sn}$, Sr, V, W. Agrochemistry, 1, 81-89.

Kolesnikov, S. I., Popovich, A. A., Kazeev, K. S. H., \& Val'kov, V. F. (2008). The influence of fluorine, boron, selenium, and arsenic pollution on the biological properties of ordinary Chernozems. Eurasian Soil Science., 41(4), 400-404.
Kolesnikov, S. I., Popovich, A. A., Kazeev, KSh., \& Val'kov, V.F. (2008). The influence of fluorine, boron, selenium, and arsenic pollution on the biological properties of ordinary Chernozems. Eurasian Soil Science., 41(4), 400-404.

Krishna, A. K., \& Mohan, K. R. (2016). Distribution, correlation, ecological and health risk assessment of heavy metal contamination in surface soils around an industrial area, Hyderabad. India. Environment and Earth Science., 2016(75), 411. https://doi.org/10.1007/ s12665-015-5151-7

LaCoste, C., Robinson, B., Brooks, R., Anderson, C., Chiarucci, A., \& Leblanc, M. (1999). The phytoremediation potential of thallium contaminated soils using Iberis and Biscutella Species". International Journal of Phytoremediation, 1, 327-338.

Lakin, H. W. (1973). Selenium in our environment. In Trace Elements in the Environment. Adv. Chem., 123, 96-111.

Li, Z. Y., Ma, Z. W., Van der Kuijp, T. J., Yuan, Z. W., \& Huang, L. (2014). A review of soil heavy metal pollution from mines in China: Pollution and health risk assessment. Sci. of Total Environ., 468, 843-853.

Liu, B., Wu, F., Li, X., Zh, Fu., Deng, Q., Mo, C., Zhu, J., Zhu, Y., \& Liao, H. (2011). Arsenic, antimony and bismuth in human hair from potentially exposed individuals in the vicinity of antimony mines in Southwest China. $J$. Microchem., 97(1), 20-24.

Liu, W., Zeng, Z., Chen, A., Zeng, G., Xiao, R., Guo, Z. H., Yi, F., Huang, Zh., He, K., \& Hu, L. (2018). Toxicity effects of silver nanoparticles on the freshwater bivalve Corbicula fluminea. //. Journal of Environmental Chemical Engineering., 6(4), 4236-4244.

Luo, Z., Uwiringiyimana, A., Zhang, Y., Guo, C., Baoshan, J.X., 2020. Thallium contamination in agricultural soils and associated potential remediation via biochar utilization. Biochar. 2.

Ma, J. F. (2003). Functions of silicon in higher plants. In P. Jeanteur, I. Kostovic, Y. Kuchino, A. Macieira-Coelho, \& R. E. Rhoads (Eds.), Mu“ller WEG (pp. 127-147). Silicon biomineralization. Springer.

Ma, J. F., Yamaji, N., Mitani, N., Tamai, K., Konishi, S., Fujiwara, T., Katsuhara, M., \& Yano, M. (2007). An efflux transporter of silicon in rice. Nature, 448(7150), 209-212.

Ma, J. F., Yamaji, N., \& Mitani-Ueno, N. (2011). Transport of silicon from roots to panicles in plants. Proc Jpn Acad Ser b., 87(7), 377-385.

Manojlović, M. S. (2003). Selenium in soil. Zbornik Matice Srpske Za Prirodne Nauke, 104, 23-37.

Martinez, M., Gutiérrez-Romero, V., Jannsens, M., Ortega-Blu, R., 2010. Biological soil quality indicators: A review. Current Research, Technology and Education Topics in Applied Microbiology and Microbial Biotechnology 319-328.

Mayland, H. F., James, L. F., Panter, K. E., \& Sonderegger, J. L. (1989). Selenium in seleniferous environments. Soil Science Society of America Journal, 23, 15-50.

Minnikova, T. V., Denisova, T. V., Mandzhieva, S. S., Kolesnikov, S. I., Minkina, T. M., Chaplygin, V. A., Burachevskaya, M. V., Sushkova, S. N., \& Bauer, T. V. 
(2017). Assessing the effect of heavy metals from the Novocherkassk power station emissions on the biological activity of soils in the adjacent areas. Journal of Geochemical Exploration., 174, 70-78. https://doi.org/10. 1016/j.gexplo.2016.06.007

Mitani, N., Chiba, Y., Yamaji, N., \& Ma, J. F. (2009). Identification and characterization of maize and barley Lsi2like silicon efflux transporters reveals a distinct silicon uptake system from that in rice. The Plant Cell, 21(7), 2133-2142.

Moschner, C., Feuerstein, U., Heilmeier, H., Zaffar, N., \& Wiche, O. (2020). Effect of substrate properties on the mobility of selected trace elements in soil and concentrations in shoots of Phalaris arundinacea. Carpathian Journal of Earth and Environmental Sciences, 15, 49-56.

Murata, T. (2006). Effects of bismuth contamination on the growth and activity of soil microorganisms using thiols as model compounds. J Environ Sci Health and Tox Hazard Subst Environ Eng., 41(2), 161-72.

Murata, T. (2010). Bismuth solubility through binding by various organic compounds and naturally occurring soil organic matter. Journal of Environmental Science and Health, Part A Environmental Science, 45, 746-753.

Murata, T., Koshikawa, M., Watanabe, M., Hou, H., \& Takamatsu, T. (2018). Migration of Ag, In, Sn, Sb, and Bi and their chemical forms in a monolith lysimeter filled with a contaminated andosol. Archives of Environmental Contamination and Toxicology., 74, 154-169.

Nadal, M., Schuhmacher, M., \& Domingo, J. L. (2011). Longterm environmental monitoring of persistent organic pollutants and metals in a chemical/petrochemical area: Human health risks. Environmental Pollution, 159, 1769-1777.

Ni, Z. N., Fu, Z., Fang, Y. F., \& Ling, K. (2011). Simultaneous multi-channel hydride generation atomic fluorescence spectrometry determination of arsenic, bismuth, tellurium and selenium in tea leaves. Food Chemistry., 124(3), 1185-1188.

Nikolaeva, O. V., \& Terekhova, V. A. (2017). Improvement of laboratory phytotest for the ecological evaluation of soils. Eurasian Soil Science, 50(9), 1105-1114.

Omouri, Z., Hawari, J., Fournier, M., \& Robidoux, P. Y. (2018). Bioavailability and chronic toxicity of bismuth citrate to earth-worm Eisenia andrei exposed to natural sandy soil. Ecotoxicology and Environmental Safety, 147, 1-8.

Pandey, S. N. (2006). Accumulation heavy metals (cadmium, cromium, copper, nickel and zinc) in Raphanus salivus L. and Spinacia olerac L. plants irrigated with industrial effluents. Journal of Environmental Biology, 27(2), 381-384.

Pavlickova, J., Zbiral, J., Smatanova, M., Habarta, P., Houserova, P., \& Kuban, V. (2006). Uptake of Thallium from artificially contaminated soils by Kale (Brassica oleracea L. var. acephala). Plant, Soil and Environment, 52, 544-549.

Pavlickova, J., Zbiral, J., Smatanova, M., Habarta, P., Houserova, P., \& Kuban, V. (2005). Uptake of Thallium from artificially and naturally contaminated soils into Rape (Brassica napus L.). J. Agr. Food Chem., 53, 2867-2871.

Plyatsuk, L. D., Chernysh, Y., Ablieieva, I., Yakhnenko, O. M., Bataltsev, Y., Balintova, M., \& Hurets, L. L. (2019).
Remediation of soil contaminated with heavy metals. Journal of Engineering Sciences., 6, 1-8.

Pontigo, S., Ribera, A., Gianfreda, L., de la Luz, M. M., Nikolic, M., \& Cartes, P. (2015). Silicon in vascular plants: Uptake, transport and its influence on mineral stress under acidic conditions. Planta, 242(1), 23-37.

Popovich, A.A., Kolesnikov, S.I., 2005. Changes in the ecological and biological properties of ordinary chernozem when contaminated with non-metallic products of technogenesis. Proceedings of higher educational institutions. North Caucasian region. Series: Natural Sciences $55,69-70$.

Pourret, O., Bollinger, J.-C., \& Hursthouse, A. (2021). Heavy metal: A misused term? Acta Geochim, 40(3), 466-471. https://doi.org/10.1007/s11631-021-00468-0

Puzanov, A. V., Baboshkina, S. V., Alekseev, I. A., \& Saltykov, A. V. (2015). Peculiarities of accumulation and distribution of heavy metals and arsenic in the system of garden soils-vegetable crops in the area of construction of the Vostochny cosmodrome (Basin of the Zeya river, Amur region). Agrochemistry, 2, 86-96.

Qing, X., Yutong, Z., \& Shenggao, L. (2015). Assessment of heavy metal pollution and human health risk in urban soils of steel industrial city (Anshan), Liaoning, Northeast China. Ecotoxicology and Environmental Safety, 120, 377-385.

Quinn, C., Freeman, J., Reynolds, R., Cappa, J., Fakra, S., Marcus, M., Lindblom, S., Quinn, E., Bennett, L., \& PilonSmits, E. (2010). Selenium hyperaccumulation offers protection from cell disruptor herbivores. BMC Ecology, $10,19$.

Reidy, B., Haase, A., Luch, A., Dawson, K. A., \& Lynch, I. (2013). Mechanisms for the isolation, transformation and toxicity of silver nanoparticles: A critical review of current knowledge and recommendations for future research and applications. Materials (basel)., 6(6), 2295-2350.

Rosenberg, E. (2009). Germanium: Environmental occurrence, importance and speciation. Reviews in Environmental Science \& Biotechnology, 8, 29-57.

Rudakiya, D. M., \& Patel, Y. (2021). Bioremediation of metals, metalloids, and nonmetals. In Book: Microbial Rejuvenation of Polluted Environment, 26, 33-49.

Sabermahani, F., Mahani, N. M., \& Noraldiny, M. (2016). Removal of thallium (I) by activated carbon prepared from apricot nucleus shell and modified with rhodamine B. Toxin Rev, 36, 154-160.

Saha, U., Fayiga, A., \& Sonon, L. (2017). Selenium in the soilplant environment: A review. International Journal of Applied Agricultural Sciences., 3(1), 1-18.

Sani A.H., Amanabo M. 2021. Lead: A concise review of its toxicity, mechanism and health effect. GSC Biological and Pharmaceutical Sciences, 2021, 15(01), 055-062. doi: https://doi.org/10.30574/gscbps.2021.15.1.0096

Sayeda, A. E. H., \& Solimanb Hamdy, A. M. (2017). Developmental toxicity and DNA damaging properties of silver nanoparticles in the catfish (Clarias gariepinus). Mutation Research Genetic Toxicology and Environmental Mutagenesis, 822, 34-40.

Sharma, V. K., Siskova, K. M., Zboril, R., \& Gardea-Torresdey, J. L. (2014). Organic-coated silver nanoparticles in biological and environmental conditions: Fate, stability 
and toxicity. Advances in Colloid and Interface Science, 204, 15-34.

Sizmur, T., Quilliam, R., Puga A.P., 2016. Application of biochar for soil remediation. In: Guo M, He Z, Uchimiya SM (eds) Agricultural and environmental applications of biochar: Advances and barriers. Soil Sci Soc. Am, Madison, 295-324.

Sudina L., Kolesnikov S., Minnikova T., Kazeev K., Sushkova S., Minkina T., 2021. Assessment of ecotoxicity of the bismuth by biological indicators of soil condition. Eurasian Journal of Soil Science 10(3), 236-242. https://doi. org/10.18393/ejss.926759.

Sun, C., Yin, N., Wen, R., Liu, W., Jia, Y., Hua, L., Zhou, Q., \& Jiang, G. (2016). Silver nanoparticles induced neurotoxicity through oxidative stress in rat cerebral astrocytes is distinct from the effects of silver ions. Neurotoxicology, 52, 210-221.

Sura-de Jong, M., Reynolds, R. J. B., Richterova, K., Musilova, L., Staicu, L. C., Chocholata, I., \& Pilon-Smits, E. (2015). Selenium hyperaccumulators harbor a diverse endophytic bacterial community characterized by high selenium resistance and plant growth promoting properties. Frontiers Plant Sci., 6, 113.

Unai Cortada, M., Hidalgo, C., Martinez, J., \& Rey, J. (2018). Impact in soil caused by metal (loid)s in lead metallurgy. The case of Cruz Smelter (Southern Spain). Journal of Geochemical Exploration, 190, 302-313.

Val'kov, V.F., Denisova, T.V., Kazeev, K.Sh., Kolesnikov, S.I., Kuznetsov, R.V., 2008. Soil fertility and agricultural plants: Ecological aspects. Rostov-on-Don, Ser. Priority national projects "Education" / Southern Federal University. 416.

Val'kov, V.F., Kazeev, K.Sh., Kolesnikov, S.I. 2008. Climatic changes and soils of the South of Russia. Proceedings of higher educational institutions. North Caucasian region. Series: Natural Sciences. 2008. 6 (148). 88-92.

Val'kov, V.F., Kazeev, K.Sh., Kolesnikov, S.I., 2012. Soils of the Rostov region: Genesis, geography and ecology. South Federal University. Rostov-on-Don, 316.

Val'kov, V. F., Kolesnikov, S. I., Kazeev, KSh., \& Tashchiev, S. S. (1997). Influence of heavy metal pollution on microscopic fungi and Azotobacter of common chernozem. Russian Journal of Ecology, 28(5), 345-346.

Viraraghavan, T., \& Srinivasan, A. (2011). Thallium: Environmental pollution and health effects. Encycl. Environ. Health., 5, 325-333.
Vodyanitskii, Yu. N. (2012). Standards for the contents of heavy metals and metalloids in soils. Eurasian Soil Science, 45(3), 321-328.

Wei, C., Deng, Q., Wu, F., Fu, Z., \& Xu, L. (2011). Arsenic, antimony, and bismuth uptake and accumulation by plants in an old antimony mine. China. Biol. Trace. Elem. Res., 144(1-3), 1150-1158.

Wiche, O. S., Balázs, M., \& Christin, H. H. (2018). Germanium in the soil-plant system - A review. Environmental Science and Pollution Research., 25, 31938-31956.

Xing, G., Zhu, J., \& Xiong, Z. (2004). Ag, Ta, Ru, and Ir enrichment in surface soil: Evidence for land pollution of heavy metal from atmospheric deposition. Global Biogeochemical Cycles, 18, 1-5.

Xiong, Q. L., Zhao, W. J., Guo, X. Y., Shu, T. T., Chen, F. T., Zheng, X. X., \& Gong, Z. N. (2015). Dustfall heavy metal pollution during winter in North China. Bulletin of Environment Contamination and Toxicology, 95(4), 548-554.

Xiong, T., Zhang, T., Dumat, C., Sobanska, S., Dappe, V., Shahid, M., Xian, Y., Li, X., Li, S., 2018. Airborne foliar transfer of particular metals in Lactuca sativa L.: Translocation, phytotoxicity, and bioaccessibility. Environmental Science and Pollution Research. 1-15.

Yamaji, N., \& Ma, J. F. (2009). A transporter at the node responsible for intervascular transfer of silicon in rice. The Plant Cell, 21(9), 2878-2883.

Yang, N., Sun, H., 2011. Bismuth: Environmental pollution and health effects. Encyclopedia of Environmental Health 414-420.

Yildirim, D., \& Sasmaz, A. (2017). Phytoremediation of As, $\mathrm{Ag}$, and $\mathrm{Pb}$ in contaminated soils using terrestrial plants grown on Gumuskoy mining area (Kutahya Turkey). Journal of Geochemical Exploration, 182, 228-234.

Yurgenson, G., \& Gorban, D. (2017). Features of bismuth distribution in soils, technosoils and plants of the Sherlovoaya mountain ore region. Internat. Jour. of Applied and Fundamental Research, 7, 111-116.

Publisher's Note Springer Nature remains neutral with regard to jurisdictional claims in published maps and institutional affiliations. 